Article

\title{
The Effects of Prolonged Storage on ARPE-19 Cells Stored at Three Different Storage Temperatures
}

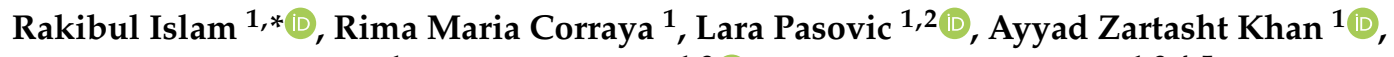 \\ Hans Christian D. Aass ${ }^{1}$, Jon Roger Eidet ${ }^{1,3} \mathbb{D}$ and Tor Paaske Utheim ${ }^{1,3,4,5}$ \\ 1 Department of Medical Biochemistry, Oslo University Hospital, 0450 Oslo, Norway; \\ rimamaria10@gmail.com (R.M.C.); larapasovic@gmail.com (L.P.); a.a.z.khan@studmed.uio.no (A.Z.K.); \\ h.c.aass@medisin.uio.no (H.C.D.A.); j.r.eidet@gmail.com (J.R.E.); utheim2@gmail.com (T.P.U.) \\ Department of Surgery, Akershus University Hospital, 1478 Lørenskog, Norway \\ Department of Ophthalmology, Oslo University Hospital, 0450 Oslo, Norway \\ Department of Ophthalmology, Stavanger University Hospital, 4011 Stavanger, Norway \\ 5 Department of Ophthalmology, Sørlandet Hospital Arendal, 4838 Arendal, Norway \\ * Correspondence: rakibul.lubikar@gmail.com; Tel.: +47-9483-7512
}

Academic Editor: Andrea Ragusa

Received: 31 October 2020; Accepted: 4 December 2020; Published: 9 December 2020

\begin{abstract}
This study aimed to investigate how prolonged storage of adult retinal pigment epithelial (ARPE-19) cell sheets affects cell metabolism, morphology, viability, and phenotype. ARPE-19 cell sheets were stored at three temperatures $\left(4^{\circ} \mathrm{C}, 16^{\circ} \mathrm{C}\right.$, and $\left.37^{\circ} \mathrm{C}\right)$ for three weeks. Metabolic status and morphology of the cells were monitored by sampling medium and examining cells by phase-contrast microscopy, respectively, throughout the storage period. Cell viability was analyzed by flow cytometry, and phenotype was determined by epifluorescence microscopy after the storage. Lactate production and glucose consumption increased heavily, while $\mathrm{pH}$ dropped considerably, through storage at $37^{\circ} \mathrm{C}$ compared to $4{ }^{\circ} \mathrm{C}$ and $16^{\circ} \mathrm{C}$. During storage, morphology started to deteriorate first at $4{ }^{\circ} \mathrm{C}$, then at $37^{\circ} \mathrm{C}$, and was maintained the longest at $16^{\circ} \mathrm{C}$. Viability of the cells after three weeks of storage was best preserved at $16^{\circ} \mathrm{C}$, while cells stored at $4{ }^{\circ} \mathrm{C}$ and $37^{\circ} \mathrm{C}$ had reduced viability. Dedifferentiation indicated by reduced expression of retinal pigment epithelium-specific protein 65 (RPE65), zonula occludens protein 1 (ZO-1), and occludin after three weeks of storage was noticed in all experimental groups compared to control. We conclude that storage temperature affects the metabolic status of ARPE- 19 cells and that $16^{\circ} \mathrm{C}$ reduces metabolic activity while protecting viability and morphology.
\end{abstract}

Keywords: retina; storage condition; temperature; regenerative medicine; cell therapy; age-related macular degeneration (AMD); oxidative stress

\section{Introduction}

The retinal pigment epithelium (RPE) is a monolayer of pigmented cells located between the neurosensory retina and the choroid [1,2]. Loss and dysfunction of RPE cells lead to major pathological changes as seen in age-related macular degeneration (AMD), Stargardt disease, and other macular dystrophies [3]. Transplantation of tissue-engineered RPE cell sheets or suspensions offers the promise of a single-intervention cure [4-7]. A growing body of preclinical studies employing several animal models and various RPE cell sources supports the feasibility of this treatment [8-22]. Several clinical studies have demonstrated promising results [23-26]. Other studies assessing the transplantation of RPE cells derived from different sources are underway [27].

The cells can be delivered to the subretinal space by means of the cell suspension or as an RPE patch $[28,29]$. However, the preparation of RPE for transplantation in humans is a complex and costly 
procedure, and upcoming regulatory demands [30] are likely to lead to the establishment of specialized cell processing centers, as described by Oie et al. for human oral mucosal cells [31]. Development of a suitable storage method will be essential to enable the transportation of cell constructs from processing centers to clinics worldwide, thereby ensuring wider access to this novel treatment.

Through several studies [32-36], we and others have explored the feasibility of establishing a xenobiotic-free storage system for RPE cells above freezing temperatures. This would circumvent the need for cryoprotectants, which are known to cause damage to stored cells [37-39]. We showed that storage at $16{ }^{\circ} \mathrm{C}$ best preserves adult retinal pigment epithelial (ARPE-19) cells stored for one week compared to eight other temperatures [32]. In the present study, we investigated the effect of storage temperature on the metabolic shift of ARPE-19 cells and evaluated the consequences measured by morphology, viability and phenotypes.

\section{Results}

\subsection{Effect of Three-Week Storage on the Metabolism of Cultured ARPE-19 Cells}

To study the effect of storage time and temperature on metabolic parameters (lactate, glucose, $\mathrm{pH}$, $\mathrm{pO}_{2}$, and $\mathrm{pCO}_{2}$ ), the storage medium was sampled every alternate day. Lactate concentration was dramatically increased after storage at $37^{\circ} \mathrm{C}(0.5-8.6 \mathrm{mmol} / \mathrm{L})$, while it was only slightly increased after storage at $4{ }^{\circ} \mathrm{C}$ and $16^{\circ} \mathrm{C}(0.1-0.5 \mathrm{mmol} / \mathrm{L}$ and $0.1-1.4 \mathrm{mmol} / \mathrm{L}$, respectively) (Figure $1 \mathrm{~A})$.

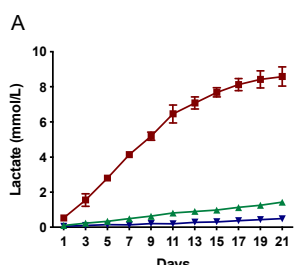

Days

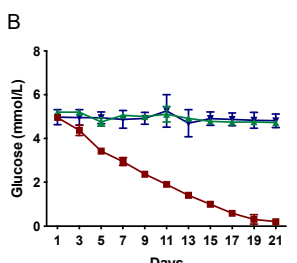

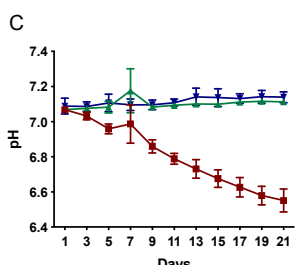

Days

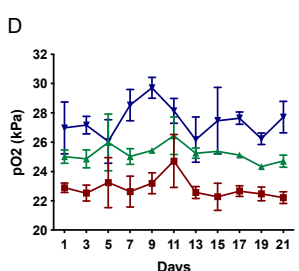

Days

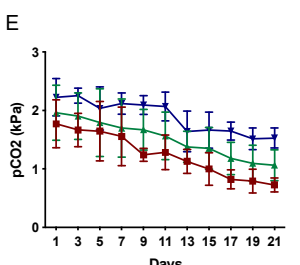

Days

Figure 1. Effect of storage temperature on the metabolic function of RPE cells. The level of lactate (A), glucose (B), $\mathrm{pH}(\mathbf{C}), \mathrm{pO}_{2}(\mathbf{D})$, and $\mathrm{pCO}_{2}(\mathbf{E})$ in the storage medium was measured every alternate day during the storage period. Data are presented as mean \pm standard deviation of the mean. $(n=8)$.

The glucose concentration decreased markedly in cultures stored at $37^{\circ} \mathrm{C}$ for three weeks $(5.0-0.2 \mathrm{mmol} / \mathrm{L})$, while only a slight reduction was noted in cultures stored at $4{ }^{\circ} \mathrm{C}$ and $16{ }^{\circ} \mathrm{C}$ $\left(5.0-4.8 \mathrm{mmol} / \mathrm{L}\right.$ and $5.2-4.7 \mathrm{mmol} / \mathrm{L}$, respectively) (Figure 1B). The $\mathrm{pH}$ was maintained at 7.1 at $4{ }^{\circ} \mathrm{C}$ and $16^{\circ} \mathrm{C}$ throughout the three weeks of storage but gradually declined at $37^{\circ} \mathrm{C}$ storage from 7.1 to 6.6 (Figure 1C). The $\mathrm{pO}_{2}$ was maintained in all temperature groups throughout the storage period $\left(27.0-27.7 \mathrm{kPa}\right.$ at $4{ }^{\circ} \mathrm{C}, 25.0-24.7 \mathrm{kPa}$ at $16^{\circ} \mathrm{C}$, and $22.9-22.2 \mathrm{kPa}$ at $37^{\circ} \mathrm{C}$ ) (Figure 1D). The $\mathrm{pCO}_{2}$ decreased gradually in all storage groups $\left(2.2-1.5 \mathrm{kPa}\right.$ at $4{ }^{\circ} \mathrm{C}, 2.0-1.1 \mathrm{kPa}$ at $16^{\circ} \mathrm{C}$, and $1.8-0.7 \mathrm{kPa}$ at $37^{\circ} \mathrm{C}$ ) (Figure 1E). The partial pressure of both $\mathrm{O}_{2}$ and $\mathrm{CO}_{2}$ was inversely proportional to the storage temperature. The metabolic investigations thus show that during the storage duration, the $16{ }^{\circ} \mathrm{C}$ conditions kept the measured parameters more stable than the $4{ }^{\circ} \mathrm{C}$ and $37^{\circ} \mathrm{C}$ groups.

\subsection{Effect of Three-Week Storage on the Morphology of Cultured ARPE-19 Cells}

To study the morphological effects of storage duration at the three different storage temperatures, phase contrast photomicrographs were captured every alternate day. Prior to storage, cells were generally well apposed and showed typical ARPE morphology (Figure 2A,M,Y). 


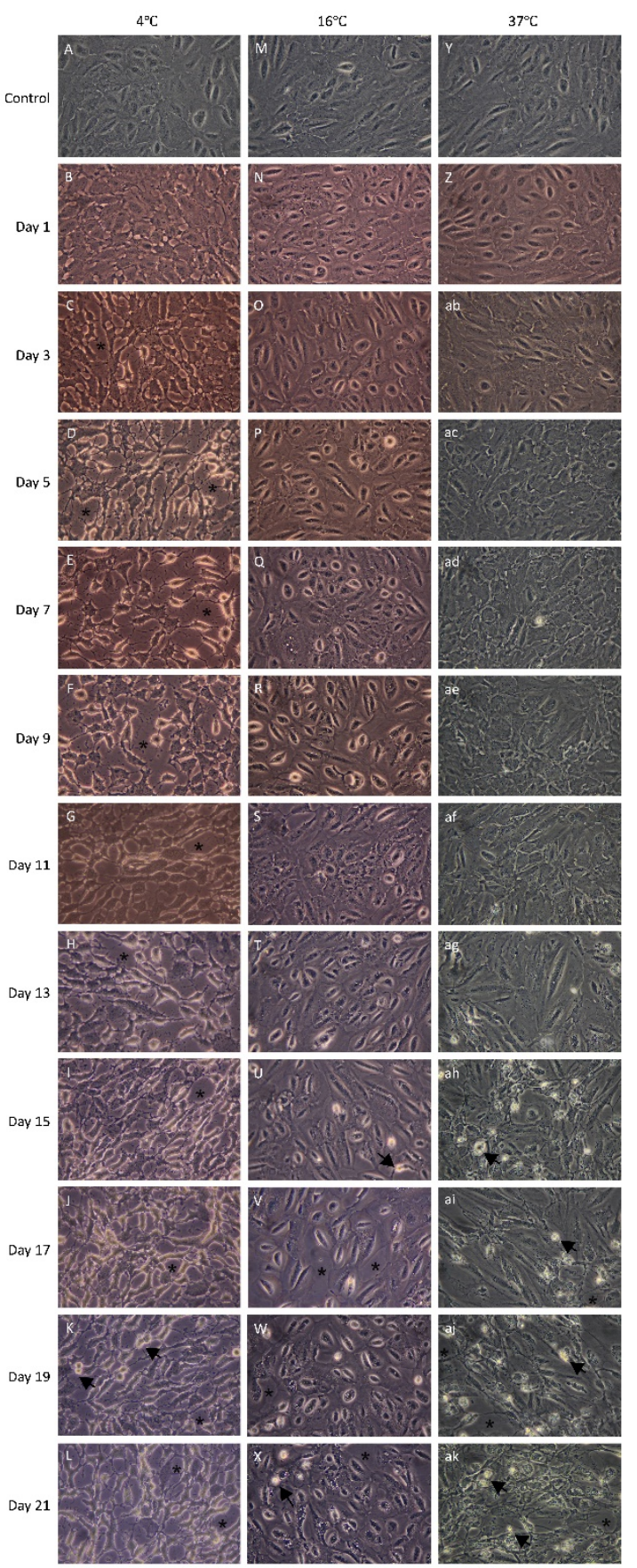

Figure 2. Effect of storage temperature on the morphology of adult retinal pigment epithelial (ARPE-19) cells. Phase-contrast photomicrographs were captured every alternate day during the storage period. Photomicrographs A, $\mathbf{M}$ and $\mathbf{Y}$ show ARPE-19 cell cultures before storage at three different temperatures. Photomicrograph B-L, N-X, and Z-ak demonstrate the morphology of the ARPE-19 cell cultures following 1 to 21 days of storage at $4{ }^{\circ} \mathrm{C}, 16^{\circ} \mathrm{C}$ and $37^{\circ} \mathrm{C}$, respectively. Black arrows indicate apoptotic cells. Asterisks indicate intercellular spacing (magnification: $400 \times ; n=4$ ).

At the end of the three-week storage period, cells stored at $16{ }^{\circ} \mathrm{C}$ showed a morphology most similar to the control. Signs of apoptosis (marked with a black arrow) and intercellular spacing (marked with an asterisk; Figure $2 \mathrm{~N}-\mathrm{X}$ ) were infrequently observed at this storage temperature. The majority of cells stored at $4{ }^{\circ} \mathrm{C}$ and $37^{\circ} \mathrm{C}$ showed signs of cell damage, apoptosis, and necrosis. These signs included extensive loss of cell-cell contact, detachment from the surrounding cells and 
shrinkage of cytoplasm. In the $4^{\circ} \mathrm{C}$ storage group, the deformation of cells was evident from day one (Figure 2B) when the cells started to shrink. In the $37^{\circ} \mathrm{C}$ group, cell detachment and fragmentation into apoptotic bodies were observed from day 13 (Figure 2ag-ak). The morphological evidence suggests that both $4{ }^{\circ} \mathrm{C}$ and $37^{\circ} \mathrm{C}$ storage conditions are suboptimal for maintaining the morphology of the cells, while $16{ }^{\circ} \mathrm{C}$ preserved it for the longest duration.

\subsection{Effect of Three-Week Storage on the Viability of Cultured ARPE-19 Cells}

To assess cell survival after storage at $4{ }^{\circ} \mathrm{C}, 16^{\circ} \mathrm{C}$ and $37^{\circ} \mathrm{C}$ for three weeks, cell viability was analyzed by measuring annexin V-binding and PI uptake using flow cytometry (Figure 3A).
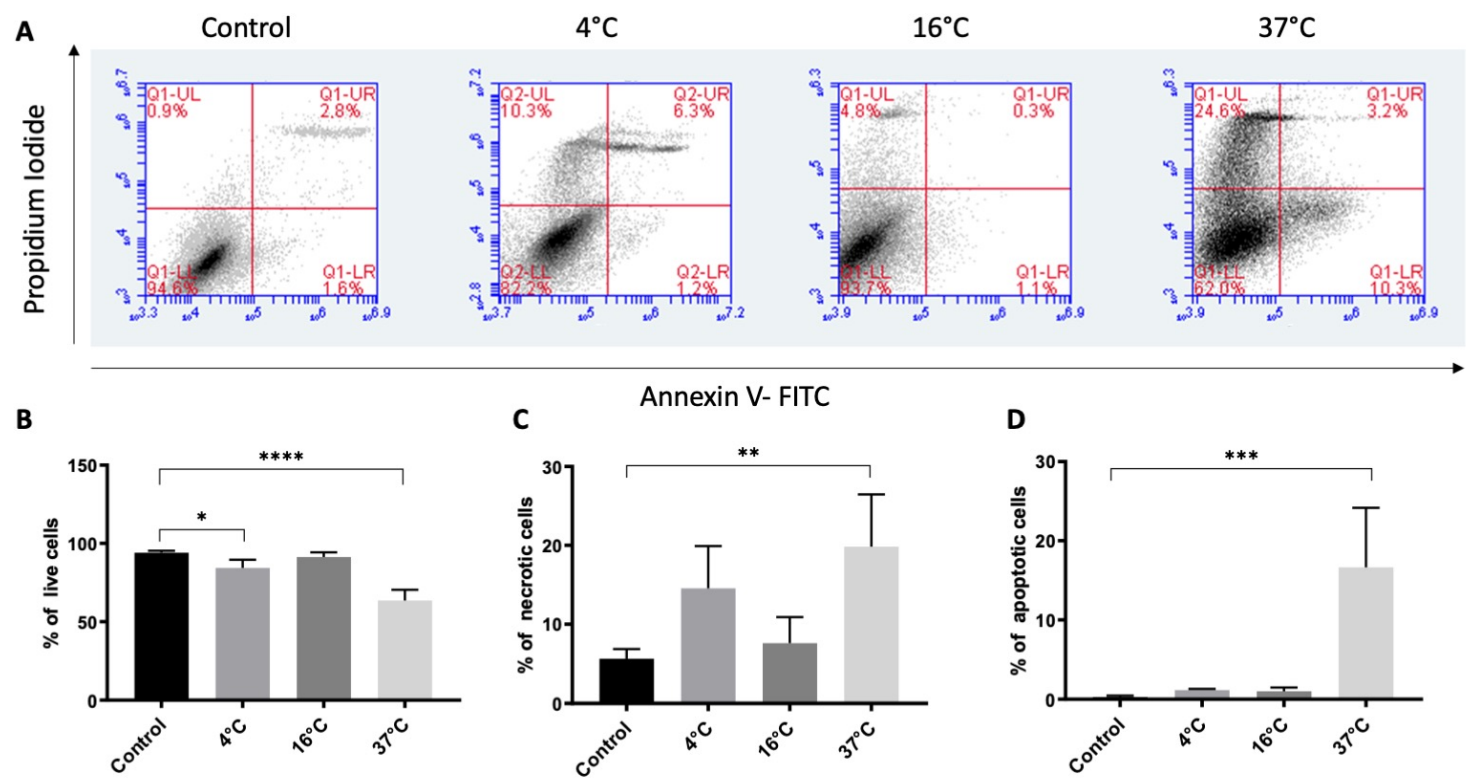

Figure 3. Effect of storage temperature on the viability of ARPE19 cells. Live, necrotic and apoptotic cells were detected by flow cytometry using annexin V and propidium iodide (PI). Cultured ARPE-19 cells were stored at three temperatures for three weeks. Dot plots (A) from the flow cytometry analysis were gated based on unstained cells for each experiment (not shown). The cell populations were distributed in four quadrants where the lower left quadrant represents live cells (annexin V and PI-negative), the upper left and right quadrants together represent necrotic cells (only PI-positive as well as both annexin V and PI-positive), while the lower right quadrant represents apoptotic cells (annexin V-positive and PI-negative). Control cells were not stored. The bar chart illustrates the percentages of live (B), necrotic $(\mathbf{C})$, and apoptotic (D) cells. Data are presented as the mean \pm standard deviation of the mean of four independent experiments. ${ }^{*} p<0.05,{ }^{* *} p<0.01,{ }^{* * *} p<0.001$, and ${ }^{* * * *} p<0.0001$.

Cell viability after three weeks of storage (defined as the percentage of cells that were annexin $\mathrm{V}$ - and PI-negative) was significantly reduced at $4{ }^{\circ} \mathrm{C}(84 \% \pm 5 \%, p=0.047)$ and $37{ }^{\circ} \mathrm{C}(63 \% \pm 6 \%$; $p<0.001)$, but not at $16^{\circ} \mathrm{C}(91 \% \pm 2 \% ; p=0.84)$, compared to the control $(94 \% \pm 1 \%)$ (Figure $\left.3 \mathrm{~B}\right)$. Necrotic cells, which were annexin V-negative and PI-positive, were significantly increased at $37^{\circ} \mathrm{C}$ $(19 \% \pm 6 \% ; p<0.001)$, but not at $4{ }^{\circ} \mathrm{C}(14 \% \pm 5 \%, p=0.07)$ or $16{ }^{\circ} \mathrm{C}(7 \% \pm 3 \%, p=0.92)$, compared to the control $(5 \% \pm 1 \%)$ (Figure 3C). Similarly, the percentage of annexin V-positive and PI-negative apoptotic cells was increased only at $37{ }^{\circ} \mathrm{C}(16 \% \pm 7 \% ; p<0.001)$, but not at $4{ }^{\circ} \mathrm{C}(1 \% \pm 0.2 \% ; p=0.99)$ or $16{ }^{\circ} \mathrm{C}$ $(1 \% \pm 0.5 \% ; p=0.99)$, compared to the control $(0.2 \% \pm 0.2 \%)$ (Figure $3 \mathrm{D})$. The viability analysis thus indicates that among the three storage conditions tested here $16^{\circ} \mathrm{C}$ condition is better for preserving cell viability similar to the non-stored cells. 


\subsection{Effect of Three-Week Storage on the Phenotype of Cultured ARPE-19 Cells}

To study the effect of storage temperature on ARPE-19 phenotype following three weeks of storage at $4{ }^{\circ} \mathrm{C}, 16^{\circ} \mathrm{C}$, and $37^{\circ} \mathrm{C}$, the cells were immunostained with four different markers. The anti-RPE65 antibody was used to target an RPE-selective protein essential for the regeneration of visual pigment [40]. RPE65-expression normalized to control (set to $100 \%$ ) appeared to be inversely proportional to the storage temperature $\left(4^{\circ} \mathrm{C}: 50 \% \pm 24 \%, p=0.011 ; 16^{\circ} \mathrm{C}: 29 \% \pm 7 \%, p<0.001 ; 37^{\circ} \mathrm{C}: 19 \% \pm 8 \%, p<0.001\right)$ (Figure 4A,B).
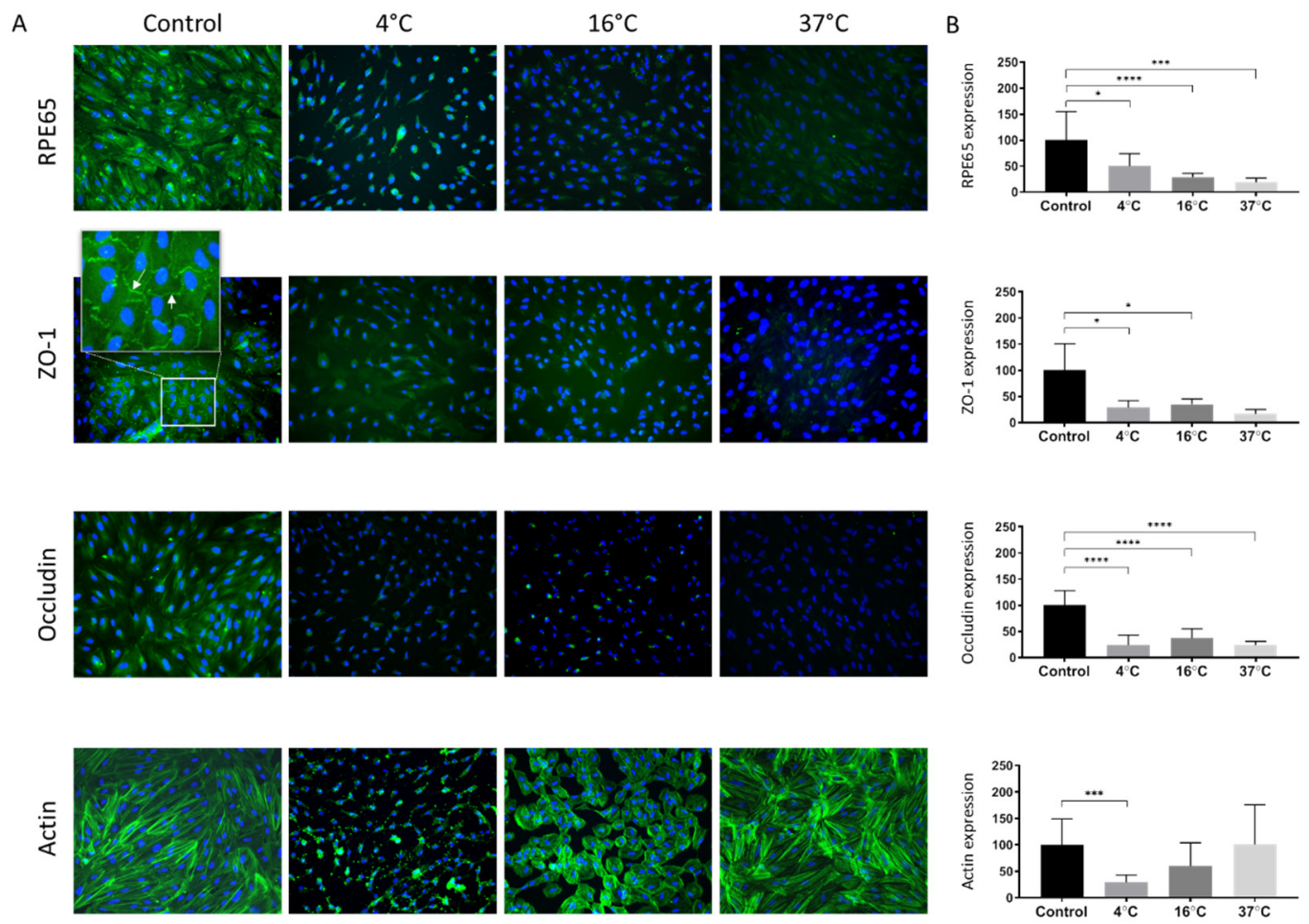

Figure 4. The effect of storage temperature on ARPE-19 cell phenotype. (A) The expression of RPE65, ZO-1 (white arrow points within a zoomed inset), occludin and actin in ARPE-19 cell cultures stored for three weeks at $4{ }^{\circ} \mathrm{C}, 16^{\circ} \mathrm{C}$, or $37^{\circ} \mathrm{C}$ was compared with non-stored control cultures. Nuclear DNA was stained with $4^{\prime}$,6-diamidino-2-phenylindole (blue). (B) Expression of the markers quantified by measuring the total fluorescence intensity normalized by cell number. The bar charts show the fluorescence intensity of anti-RPE65, anti-ZO-1, anti-occludin, and anti-actin relative to control cultures $(100 \%)$. Magnification 200×. Data are expressed as mean \pm standard deviation of the mean. ${ }^{*} p<0.05$, *** $p<0.001$ and ${ }^{* * * *} p<0.0001$.

To assess the presence of intercellular tight junctions, staining with anti-ZO- 1 and anti-occludin antibodies was performed. The ZO-1 marker localized to cell borders and was present between all apposed cells in the control group, indicating a tight junction organization typical of native RPE (Figure 4A). Compared to the non-stored control (set to 100\%; Figure 4A,B) ZO-1-expression was reduced following storage at all storage temperatures $(29 \% \pm 13 \%, p=0.035 ; 35 \% \pm 10 \%, p=0.0155$ and $17 \% \pm 8 \%, p=0.0510$ for $4,16^{\circ} \mathrm{C}$ and $37^{\circ} \mathrm{C}$, respectively). Occludin, another tight junction marker, was also significantly reduced following storage at all storage temperatures $(24 \% \pm 19 \%, p<0.001$; $37 \% \pm 18 \%, p<0.001$; and $24 \% \pm 7, p<0.001$; for $4{ }^{\circ} \mathrm{C}, 16^{\circ} \mathrm{C}$, and $37^{\circ} \mathrm{C}$, respectively) compared to the non-stored control (set to 100\%; Figure 4A,B).

Alexa Fluor 568 phalloidin staining was applied for selective labeling of F-actin in order to visualize the cytoskeleton and evaluate the formation of stress fibers. Actin staining revealed a continuous cytoplasmic network of filamentous structures in the control cultures, with the formation of stress 
fibers seen in some cells (Figure $4 \mathrm{~A}$ ). After storage at $4{ }^{\circ} \mathrm{C}$, there was disorganization and complete loss of actin filamentous structure (Figure $4 \mathrm{~A}$ ). However, in the $16^{\circ} \mathrm{C}$ group, actin filaments were less stretched and more circular, whereas the filaments were maintained after storage at $37^{\circ} \mathrm{C}$ compared to the control (Figure 4A). Measuring the fluorescence intensity of the filament staining showed that at $4{ }^{\circ} \mathrm{C}$ storage it was significantly lower $(28 \% \pm 14 \% ; p<0.001)$ compared to the control (Figure $\left.4 \mathrm{~B}\right)$, while, there was no statistically significant difference at $16^{\circ} \mathrm{C}$ storage $(60 \% \pm 43 \% ; p=0.070)$ at $37^{\circ} \mathrm{C}$ $(100 \% \pm 75 \% ; p>0.999)$ after three weeks (Figure 4A,B).

\section{Discussion}

In this study, we investigated how prolonged storage of ARPE-19 cell sheets affects cell metabolism, morphology, viability, and phenotype. We found that the temperature affects the metabolic shift over time. Among the three temperature groups, $16^{\circ} \mathrm{C}$ kept the metabolic shift low, cell viability high, and morphology preserved. However, the phenotype was not maintained at control levels after storage at any of the temperatures.

Our results demonstrated an increased breakdown of glucose to lactate with a concomitant reduction in $\mathrm{pH}$ during storage at $37^{\circ} \mathrm{C}$ compared to $4{ }^{\circ} \mathrm{C}$ and $16^{\circ} \mathrm{C}$. This is in accordance with earlier findings in stored human-induced pluripotent stem cell-derived retinal pigment epithelium cells [36], epidermal cell sheets [41], cultured human conjunctival cells [42] and human oral keratinocytes [43]. The high lactate/glucose ratio indicates that the glycolytic pathway accounts for a large part of energy production from glucose and could possibly represent a cellular adjustment to avoid an excessive production of damaging reactive oxygen species generated through the oxidative phosphorylation pathway [44]. Lactate concentration at $37^{\circ} \mathrm{C}$ storage rose linearly until day 11, after which it started to level off, possibly due to accelerated cell death. In fact, when evaluating the corresponding microscopy images of the same storage group, it appears that apoptotic bodies started to form after day 11 . This could be related to the considerable drop in $\mathrm{pH}$ at $37^{\circ} \mathrm{C}$ storage, which can induce cell apoptosis [45]. Since the storage media is easily accessible without affecting the cells, therefore, the lactate, glucose, and $\mathrm{pH}$ values together may be considered as critical quality control parameters for RPE-cells during storage at $37^{\circ} \mathrm{C}$. At $4{ }^{\circ} \mathrm{C}$ and $16^{\circ} \mathrm{C}$ storage, the changes in the metabolic parameters were not as dramatic as $37^{\circ} \mathrm{C}$. At $4{ }^{\circ} \mathrm{C}$ storage, cells exhibited typical signs of apoptosis and necrosis early on during storage without any obvious connection to metabolic parameters. At $4{ }^{\circ} \mathrm{C}$, cells die mainly because of low temperature-related stress [32], whereas, at $37^{\circ} \mathrm{C}$, the primary causes may be associated with accumulation of lactate, $\mathrm{pH}$ reduction and associated apoptosis [43,45]. At 16 ${ }^{\circ} \mathrm{C}$, the morphology of the cells was maintained the longest without dramatic changes in metabolic parameters. Thus, storage at $16{ }^{\circ} \mathrm{C}$ reduced the metabolic rate of the cells while not exerting the detrimental effect of low temperature-associated stress [43].

This explanation is corroborated by the post-storage viability, which demonstrated that after $16{ }^{\circ} \mathrm{C}$ storage, the live-cell percentage did not significantly differ from non-stored control cells (Figure 3). In a study by Kitahata et al., cell suspension of human-induced pluripotent stem-cell-derived retinal pigment epithelium cells demonstrated a higher percentage of viable cells at $16^{\circ} \mathrm{C}$ compared to $4{ }^{\circ} \mathrm{C}$, $25^{\circ} \mathrm{C}$ and $37^{\circ} \mathrm{C}$ following $24 \mathrm{~h}$ of storage [36]. However, our previous study demonstrated the viability of about $50 \%$ after one-week storage at $16^{\circ} \mathrm{C}$ [32]. This discrepancy can be explained by a change in the viability assessment analysis. In the present study, we used flow cytometry to measure the expression of the apoptotic marker, phosphatidylserine, by binding of annexin $\mathrm{V}$ and determine the dead cells by PI staining. Viability was calculated as the percentage of non-stained cells from total acquired cells suspension for the analysis. In the previous study, viability was not assessed in the suspended cells, rather as fluorescence intensity of calcein-acetoxymethyl ester staining on adherent cells determined by a microplate fluorometer.

The RPE is a highly specialized tissue performing several functions that are crucial for sight, including phagocytosis of shed photoreceptor outer segments, regeneration of visual cycle pigments, and transport of nutrients and fluid between the choroid and neuroretina $[3,46]$. These traits are affected 
by macular disease and could be remedied by transplanted tissue. It is, therefore, important that transplanted cells display differentiated RPE properties. The ARPE-19 cell line is a widely employed model for the study of RPE biology. While it displays significant functional differentiation [47,48], it does not mirror all characteristics of native RPE, and its phenotype is highly dependent on culture conditions [49-52]. However, the use of serum-free media and plastic substrates, which are employed herein, have been shown to reduce dedifferentiation in culture [49,53]. Earlier, we showed that ARPE-19 cells stored at $16^{\circ} \mathrm{C}$ for one week are capable of maintaining the expression of the RPE differentiation marker RPE65 [32]. The current results demonstrated a reduced RPE65 expression at $16^{\circ} \mathrm{C}$ following three weeks' storage compared to one-week storage, which may indicate dedifferentiation of ARPE-19 cells with increasing storage duration. Similarly, we earlier showed maintained expression of the tight junction markers ZO-1 and occludin after one-week storage of ARPE-19 cells [32,33]. The expression of these markers is not maintained after three weeks' storage. The effect of storage on cell phenotype has been described previously for several cell types. Studies have demonstrated that cultured limbal cells can be stored for one week in an organ culture medium at $23{ }^{\circ} \mathrm{C}$ with intact phenotype [54]. Similarly, cultured human oral keratinocytes can be stored under the conditions described herein for one week without signs of differentiation [43]. Microarray analysis demonstrated upregulation of tight junction proteins after one-week storage at $37^{\circ} \mathrm{C}$ compared to $12{ }^{\circ} \mathrm{C}$, indicating an increased synthesis of tight junctions in $\mathrm{HOK}$ cells stored at $37^{\circ} \mathrm{C}$ [55]. In cultured epidermal cell sheets stored at different temperatures for two weeks, there was a tendency of increased expression of differentiation markers at all temperatures except for $12{ }^{\circ} \mathrm{C}$ [56]. Based on these observations, it seems that the phenotypic plasticity during storage varies between different cell types.

In the present study, there were also changes in the distribution of the actin cytoskeleton, which is important for cell adhesion, morphogenesis, and phagocytosis. Contractile actomyosin bundles called stress fibers assemble following mechanical stress and are common in cultured epithelial cells $[57,58]$. Actin staining revealed a continuous cytoplasmic network of filamentous structures in the control cultures, with the formation of stress fibers seen in some cells. These features were maintained after storage at $37^{\circ} \mathrm{C}$. After storage at $4{ }^{\circ} \mathrm{C}$ and $16^{\circ} \mathrm{C}$, however, there was a disruption of the actinic cytoskeleton. Disrupted staining patterns of the actin cytoskeleton, tight junctions, and adherens junctions in the RPE in relation to elevated reactive oxygen species were previously reported elsewhere. [59] ARPE-19 cells stored at $16^{\circ} \mathrm{C}$ for one week displayed a similar distribution with a predominantly circumferential actin arrangement and fewer elongated cells than control cultures [32].

Replacement of the diseased RPE is on the verge of becoming a reality in regenerative therapies to cure age-related macular degenerative diseases. The successful outcome with the first two patients from a clinical study by transplanting cultured cell sheet has demonstrated the potential effectiveness of the therapy [26]. The development of complementary storage techniques for RPE transplants is likely to have a large medical impact as it allows flexibility in scheduling surgery and can widen patients' access to future applications of regenerative therapy.

We conclude from our study that the storage temperature affects the metabolic status of ARPE-19 cells and that $16^{\circ} \mathrm{C}$ is superior for keeping the metabolic activity low while protecting the viability and morphology. Our study infers the importance of monitoring metabolic parameters as quality control of the stored ARPE-19 cells.

\section{Materials and Methods}

\subsection{Cell Culture Media and Reagents}

ARPE-19 cells were obtained from the American Type Culture Collection (ATCC) (Manassas, VA, USA). Dulbecco's Modified Eagle's Medium: nutrient mixture F12 (hereafter named DMEM:F12), fetal bovine serum (FBS), bovine serum albumin (BSA), trypsin-EDTA, 4-(2-hydroxyethyl)-1-piperazineethanesulfonic acid (HEPES), sodium bicarbonate, gentamycin, phosphate-buffered saline (PBS), penicillin, streptomycin, 4', 6 -diamidino-2-phenylindole (DAPI), propidium iodide (PI), Tween-20 and PAP pen were purchased 
from Sigma-Aldrich (St. Louis, MO, USA). Fluorescein isothiocyanate (FITC)-labeled annexin V (to bind PS), annexin V-binding buffer containing $10 \mathrm{mM}$ HEPES (pH 7.4), $140 \mathrm{mM} \mathrm{NaCl}$, and $2.5 \mathrm{mM} \mathrm{CaCl}_{2}$, were purchased from Becton Dickinson Biosciences (BD), Belgium. Minimum essential medium (MEM) was purchased from Invitrogen (Carlsbad, CA, USA). Pipettes, $25 \mathrm{~cm}^{2}$ flasks, $15 \mathrm{~mL}$ and $50 \mathrm{~mL}$ centrifugation tubes, 1 L glass bottles, and pipette tips were supplied by VWR International (West Chester, PA, USA). Vacuum filtration rapid filter mix was supplied by BioNordika (Oslo, Norway). Mouse anti-RPE65, rabbit anti-occludin, FITC-conjugated goat anti-mouse IgG and FITC-conjugated goat anti-rabbit IgG antibodies were obtained from Abcam (Cambridge, UK). Mouse anti-ZO-1 and Alexa Fluor 568 phalloidin were purchased from Life Technologies (Carlsbad, CA, USA).

\subsection{Culture of ARPE-19 Cells}

Human ARPE-19 cells were routinely cultured in $95 \%$ air and $5 \% \mathrm{CO}_{2}$ at $37^{\circ} \mathrm{C}$ in DMEM:F12 containing $10 \%$ FBS, 50 units $/ \mathrm{mL}$ penicillin and $50 \mu \mathrm{g} / \mathrm{mL}$ streptomycin. The cells at passage 6 were seeded (120,000 cells/flask) in $25 \mathrm{~cm}^{2}$ culture flasks with filter closer. The culture medium was changed every other day, and confluent cultures were obtained on the sixth day. Control cultures, which were not subjected to subsequent storage, were immediately prepared for the various analyses.

\subsection{Storage of ARPE-19 Cells}

After the six-days culture period, the T25 flasks were removed from the incubator, and the culture medium was replaced by a storage medium consisting of $9.53 \mathrm{~g}$ MEM, $25 \mathrm{mM}$ HEPES, $600 \mathrm{mg} / \mathrm{L} \mathrm{sodium}$ bicarbonate and $50 \mu \mathrm{g} / \mathrm{mL}$ gentamycin in $1 \mathrm{~L}$ distilled water. The filter cap of the flasks was changed to a solid cap to avoid evaporation during storage. Thereafter, the cultures were randomized for storage at three temperatures $\left(4^{\circ} \mathrm{C}, 16^{\circ} \mathrm{C}\right.$ and $\left.37^{\circ} \mathrm{C}\right)$ for three weeks in storage containers without $\mathrm{CO}_{2}$ supply. The storage containers have been described previously [32]. The stability of the temperature inside the storage containers has been reported [60] and was controlled regularly throughout all experiments.

\subsection{Metabolic Analysis}

Samples of the storage medium $(2 \mathrm{~mL})$ were taken every alternate day from day 1 to day 21 and were analyzed using a Radiometer ABL 700 blood gas analyzer (Radiometer, Bronshoj, Denmark) at room temperature. The following parameters were studied: $\mathrm{pH}$, glucose, lactate, partial pressure of oxygen $\left(\mathrm{pO}_{2}\right)$ and partial pressure of carbon dioxide $\left(\mathrm{pCO}_{2}\right)$. The experiment was repeated eight times $(n=8)$.

\subsection{Morphology Analysis}

Morphology of the stored ARPE-19 cell cultures was assessed by light microscopy every alternate day during the storage period. The experiment was repeated four times $(n=4)$. Photomicrographs were captured at 400× magnification using a Leica DM IL LED microscope and a Canon EOS 5D Mark II camera.

\subsection{Viability Analysis}

Viability after three weeks of storage was analyzed by a flow cytometer (BD Accuri C6 flow cytometer, Becton Dickinson, CA, USA) using FITC-conjugated annexin V and PI. Annexin V binds selectively to phosphatidylserine (in the presence of calcium ions), which is anchored at the cytosolic face of the plasma membrane in viable cells. During the early phases of apoptosis, phosphatidylserine is re-localized to the outer surface of the plasma membrane, where it can be detected with fluorescently labeled annexin V [61]. Apoptotic cells were defined as annexin V-positive and PI-negative. PI passes through permeable cell membranes of necrotic cells and stains double-stranded DNA. Viable cells were defined as both annexin V-and PI-negative. 
The analysis was performed according to the protocol provided by the supplier and repeated four times $(n=4)$. Briefly, RPE cells were trypsinized and centrifuged at room temperature. The supernatant was aspirated from the cell pellet, which was resuspended in $200 \mu \mathrm{L}$ of annexin V-binding buffer containing annexin V-FITC $(1 \mu \mathrm{L} / \mathrm{mL})$ and incubated for $25 \mathrm{~min}$ at room temperature. PI dye $(10 \mu \mathrm{g} / \mathrm{mL})$ was added for further 5-min incubation at room temperature before the suspension was analyzed using a flow cytometer.

\subsection{Phenotype Analysis}

Cells were cultured in T25 flasks and stored at $4{ }^{\circ} \mathrm{C}, 16{ }^{\circ} \mathrm{C}$ and $37{ }^{\circ} \mathrm{C}$ for three weeks, as described above. Samples were subsequently prepared for immunocytochemical characterization with $30 \mathrm{~min}$ of $4 \%$ formaldehyde fixation at room temperature followed by one hour of permeabilization and blocking in PBS containing 1\% BSA and $0.01 \%$ Tween-20. Control cells were processed for immunocytochemistry immediately after the six-day culture period. Anti-RPE65 (1:50), anti-ZO-1 (1:50) and anti-occludin (1:50) antibodies were diluted in blocking solution (PBS with 1\% BSA). In the negative controls, primary antibodies were substituted with PBS. Samples were incubated for one hour at room temperature. FITC-conjugated goat anti-mouse secondary antibodies (diluted 1:200 in blocking solution) and FITC-conjugated goat anti-rabbit secondary antibodies (1:250) were added for one hour at room temperature. Specimens were washed three times in PBS, and $1 \mu \mathrm{g} / \mathrm{mL}$ DAPI was added during the last wash to stain the nuclear DNA. To visualize the actin cytoskeleton, samples were fixed, blocked, and permeabilized as described above and stained with 100 units/mL, which is equivalent to approximately $20 \mu \mathrm{M}$ Alexa Fluor 568 phalloidin. After incubating for $1 \mathrm{~h}$ at room temperature, specimens were washed in PBS and stained with DAPI.

The samples were studied using a Nikon Eclipse Ti fluorescence microscope and photographed at $\times 200$ magnification with a DS-Qi1 black-and-white camera. Identical exposure length and gain were maintained for all compared samples, and the image brightness was within the dynamic range of the camera. The experiments were repeated four times $(n=4)$.

The photomicrographs were then objectively assessed using ImageJ software (National Institutes of Health, Bethesda, MD, USA) as described previously [62], with some modifications. In brief, for DAPI count, 16-bit photomicrographs of DAPI-stained nuclei were converted to 8-bit images before being auto-thresholded to binary photos using the "Make Binary" function in ImageJ. Touching cell nuclei were separated by the "Watershed" command. Cell debris and other smaller cellular particles were excluded from analysis on the basis of size by the "Analyze Particle" function. For phenotypic quantification, unevenly transmitted light was subtracted from all 16-bit photomicrographs using the "Subtract Background (rolling = 50)" command in ImageJ before the total fluorescence intensity was measured. Finally, the total fluorescence intensity in each photomicrograph was divided by the number of DAPI-stained nuclei in each corresponding DAPI-photomicrograph. By using this method, we were able to normalize for differences in cell density in each photomicrograph.

\subsection{Statistical Analysis}

A one-way analysis of variance with Tukey's post hoc comparisons (SPSS ver. 19.0 or GraphPad prism 8.2.1) was used for statistical evaluation of the results. $P$ values below 0.05 were considered significant.

Author Contributions: Conceptualization, T.P.U., J.R.E., R.M.C., R.I.; methodology, R.M.C., R.I., H.C.D.A.; software, A.Z.K.; formal analysis, R.I., A.Z.K.; investigation, R.M.C., R.I.; resources, T.P.U.; writing-original draft preparation, R.I., R.M.C., L.P.; writing-review and editing, R.I., R.M.C., L.P., A.Z.K., H.C.D.A., J.R.E., T.P.U.; visualization, R.I., H.C.D.A.; supervision, J.R.E., T.P.U.; project administration, R.M.C. and R.I.; funding acquisition, T.P.U. All authors have read and agreed to the published version of the manuscript.

Funding: This research received no external funding.

Conflicts of Interest: The authors declare no conflict of interest. The funders had no role in the design of the study; in the collection, analyses, or interpretation of data; in the writing of the manuscript, or in the decision to publish the results. 


\section{References}

1. Marmorstein, A.D. The Polarity of the Retinal Pigment Epithelium. Traffic 2001, 2, 867-872. [CrossRef]

2. De Jong, P.T.V.M. Age-related macular degeneration. N. Engl. J. Med. 2006, 355, 1474-1485. [CrossRef]

3. Hicks, D.; Hamel, C.P. The Retinal Pigment Epithelium in Health and Disease. Curr. Mol. Med. 2010, 10, 802-823. [CrossRef]

4. Vaajasaari, H.; Ilmarinen, T.; Juuti-Uusitalo, K.; Rajala, K.; Onnela, N.; Narkilahti, S.; Suuronen, R.; Hyttinen, J.; Uusitalo, H.; Skottman, H. Toward the defined and xeno-free differentiation of functional human pluripotent stem cell-derived retinal pigment epithelial cells. Mol. Vis. 2011, 17, 558-575.

5. Alexander, P.; Thomson, H.A.J.; Luff, A.J.; Lotery, A.J. Retinal pigment epithelium transplantation: Concepts, challenges, and future prospects. Eye 2015, 29, 992-1002. [CrossRef]

6. Nazari, H.; Zhang, L.; Zhu, D.; Chader, G.J.; Falabella, P.; Stefanini, F.R.; Rowland, T.J.; Clegg, D.O.; Kashani, A.H.; Hinton, D.R.; et al. Stem cell based therapies for age-related macular degeneration: The promises and the challenges. Prog. Retin. Eye Res. 2015, 48, 39. [CrossRef]

7. Mandai, M.; Watanabe, A.; Kurimoto, Y.; Hirami, Y.; Morinaga, C.; Daimon, T.; Fujihara, M.; Akimaru, H.; Sakai, N.; Shibata, Y.; et al. Autologous Induced Stem-Cell-Derived Retinal Cells for Macular Degeneration. N. Engl. J. Med. 2017, 376, 1038-1046. [CrossRef]

8. Crafoord, S.; Algvere, P.V.; Seregard, S.; Kopp, E.D. Long-term outcome of RPE allografts to the subretinal space of rabbits. Acta Ophthalmol. Scand. 1999, 77, 247-254. [CrossRef] [PubMed]

9. Lund, R.D.; Adamson, P.; Sauvé, Y.; Keegan, D.J.; Girman, S.V.; Wang, S.; Winton, H.; Kanuga, N.; Kwan, A.S.L.; Beauchène, L.; et al. Subretinal transplantation of genetically modified human cell lines attenuates loss of visual function in dystrophic rats. Proc. Natl. Acad. Sci. USA 2001, 98, 9942-9947. [CrossRef]

10. Wang, H.; Leonard, D.S.; Castellarin, A.; Tsukahara, I.; Ninomiya, Y.; Yagi, F.; Cheewatrakoolpong, N.; Sugino, I.K.; Zarbin, M. Short-term study of allogeneic retinal pigment epithelium transplants onto debrided Bruch's membrane. Investig. Ophthalmol. Vis. Sci. 2001, 42, 2990-2999.

11. Coffey, P.J.; Girman, S.; Wang, S.M.; Hetherington, L.; Keegan, D.J.; Adamson, P.; Greenwood, J.; Lund, R.D. Long-term preservation of cortically dependent visual function in RCS rats by transplantation. Nat. Neurosci. 2001, 5, 53-56. [CrossRef] [PubMed]

12. Girman, S.V.; Wang, S.; Lund, R.D. Cortical visual functions can be preserved by subretinal RPE cell grafting in RCS rats. Vis. Res. 2003, 43, 1817-1827. [CrossRef]

13. Haruta, M.; Sasai, Y.; Kawasaki, H.; Amemiya, K.; Ooto, S.; Kitada, M.; Suemori, H.; Nakatsuji, N.; Ide, C.; Honda, Y.; et al. In vitro and in vivo characterization of pigment epithelial cells differentiated from primate embryonic stem cells. Investig. Opthalmol. Vis. Sci. 2004, 45, 1020-1025. [CrossRef] [PubMed]

14. McGill, T.; Lund, R.; Douglas, R.; Wang, S.; Lu, B.; Prusky, G. Preservation of vision following cell-based therapies in a model of retinal degenerative disease. Vis. Res. 2004, 44, 2559-2566. [CrossRef]

15. Del Priore, L.V.; Tezel, T.H.; Kaplan, H.J. Survival of allogeneic porcine retinal pigment epithelial sheets after subretinal transplantation. Investig. Opthalmol. Vis. Sci. 2004, 45, 985-992. [CrossRef]

16. Wang, S.; Lu, B.; Wood, P.; Lund, R.D. Grafting of ARPE-19 and Schwann Cells to the Subretinal Space in RCS Rats. Investig. Opthalmol. Vis. Sci. 2005, 46, 2552-2560. [CrossRef]

17. Lund, R.D.; Wang, S.; Klimanskaya, I.; Holmes, T.; Ramos-Kelsey, R.; Lu, B.; Girman, S.; Bischoff, N.; Sauvé, Y.; Lanza, R. Human Embryonic Stem Cell-Derived Cells Rescue Visual Function in Dystrophic RCS Rats. Cloning Stem Cells 2006, 8, 189-199. [CrossRef]

18. Yaji, N.; Yamato, M.; Yang, J.; Okano, T.; Hori, S. Transplantation of tissue-engineered retinal pigment epithelial cell sheets in a rabbit model. Biomaterials 2009, 30, 797-803. [CrossRef]

19. Carr, A.-J.F.; Vugler, A.A.; Hikita, S.T.; Lawrence, J.M.; Gias, C.; Chen, L.L.; Buchholz, D.E.; Ahmado, A.; Semo, M.; Smart, M.J.K.; et al. Protective Effects of Human iPS-Derived Retinal Pigment Epithelium Cell Transplantation in the Retinal Dystrophic Rat. PLoS ONE 2009, 4, e8152. [CrossRef]

20. Hu, Y.; Liu, L.; Lu, B.; Zhu, D.; Ribeiro, R.; Diniz, B.; Thomas, P.B.; Ahuja, A.K.; Hinton, D.R.; Tai, Y.-C.; et al. A Novel Approach for Subretinal Implantation of Ultrathin Substrates Containing Stem Cell-Derived Retinal Pigment Epithelium Monolayer. Ophthalmic Res. 2012, 48, 186-191. [CrossRef] 
21. Li, Y.; Tsai, Y.-T.; Hsu, C.-W.; Erol, D.; Yang, J.; Wu, W.-H.; Davis, R.J.; Egli, D.; Tsang, S.H. Long-term Safety and Efficacy of Human-Induced Pluripotent Stem Cell (iPS) Grafts in a Preclinical Model of Retinitis Pigmentosa. Mol. Med. 2012, 18, 1312-1319. [CrossRef] [PubMed]

22. Sun, J.; Mandai, M.; Kamao, H.; Hashiguchi, T.; Shikamura, M.; Kawamata, S.; Sugita, S.; Takahashi, M. Protective Effects of Human iPS-Derived Retinal Pigmented Epithelial Cells in Comparison with Human Mesenchymal Stromal Cells and Human Neural Stem Cells on the Degenerating Retina inrd1mice. Stem Cells 2015, 33, 1543-1553. [CrossRef]

23. Schwartz, S.D.; Hubschman, J.-P.; Heilwell, G.; Franco-Cardenas, V.; Pan, C.K.; Ostrick, R.M.; Mickunas, E.; Gay, R.; Klimanskaya, I.; Lanza, R. Embryonic stem cell trials for macular degeneration: A preliminary report. Lancet 2012, 379, 713-720. [CrossRef]

24. Schwartz, S.D.; Regillo, C.D.; Lam, B.L.; Eliott, D.; Rosenfeld, P.J.; Gregori, N.Z.; Hubschman, J.-P.; Davis, J.L.; Heilwell, G.; Spirn, M.; et al. Human embryonic stem cell-derived retinal pigment epithelium in patients with age-related macular degeneration and Stargardt's macular dystrophy: Follow-up of two open-label phase 1/2 studies. Lancet 2015, 385, 509-516. [CrossRef]

25. Schwartz, S.D.; Tan, G.; Hosseini,H.; Nagiel, A. Subretinal Transplantation of Embryonic Stem Cell-Derived Retinal Pigment Epithelium for the Treatment of Macular Degeneration: An Assessment at 4 Years. Investig. Opthalmol. Vis. Sci. 2016, 57, ORSFc1-ORSFc9. [CrossRef]

26. Da Cruz, L.; Fynes, K.; Georgiadis, O.; Kerby, J.; Luo, Y.H.; Ahmado, A.; Vernon, A.; Daniels, J.T.; Nommiste, B.; Hasan, S.M.; et al. Phase 1 clinical study of an embryonic stem cell-derived retinal pigment epithelium patch in age-related macular degeneration. Nat. Biotechnol. 2018, 36, 328-337. [CrossRef]

27. Bracha, P.; A Moore, N.; A Ciulla, T. Induced pluripotent stem cell-based therapy for age-related macular degeneration. Expert Opin. Biol. Ther. 2017, 17, 1113-1126. [CrossRef]

28. Ramsden, C.M.; Powner, M.B.; Carr, A.-J.F.; Smart, M.J.K.; Da Cruz, L.; Coffey, P.J. Stem cells in retinal regeneration: Past, present and future. Deversity 2013, 140, 2576-2585. [CrossRef]

29. Ramsden, C.M.; Da Cruz, L.; Coffey, P. Stemming the Tide of Age-Related Macular Degeneration: New Therapies for Old Retinas. Investig. Opthalmol. Vis. Sci. 2016, 57. [CrossRef]

30. Daniels, J.T.; Secker, G.A.; Shortt, A.J.; Tuft, S.J.; Seetharaman, S. Stem cell therapy delivery: Treading the regulatory tightrope. Regen. Med. 2006, 1, 715-719. [CrossRef]

31. Oie, Y.; Nozaki, T.; Takayanagi, H.; Hara, S.; Hayashi, R.; Takeda, S.; Mori, K.; Moriya, N.; Soma, T.; Tsujikawa, M.; et al. Development of a Cell Sheet Transportation Technique for Regenerative Medicine. Tissue Eng. Part C Methods 2014, 20, 373-382. [CrossRef] [PubMed]

32. Pasovic, L.; Utheim, T.P.; Maria, R.; Lyberg, T.; Messelt, E.B.; Aabel, P.; Chen, D.F.; Chen, X.; Eidet, J.R. Optimization of Storage Temperature for Cultured ARPE-19 Cells. J. Ophthalmol. 2013, $2013,11$. [CrossRef] [PubMed]

33. Pasovic, L.; Eidet, J.R.; Brusletto, B.S.; Lyberg, T.; Utheim, T.P. Effect of Storage Temperature on Key Functions of Cultured Retinal Pigment Epithelial Cells. J. Ophthalmol. 2015, 2015, 10. [CrossRef] [PubMed]

34. Pasovic, L.; Eidet, J.R.; Olstad, O.K.; Chen, D.F.; Lyberg, T.; Utheim, T.P. Impact of Storage Temperature on the Expression of Cell Survival Genes in Cultured ARPE-19 Cells. Curr. Eye Res. 2016, 42, 134-144. [CrossRef]

35. Khan, A.Z.; Utheim, T.P.; Reppe, S.; Sandvik, L.; Lyberg, T.; Roald, B.B.-H.; Ibrahim, I.B.; Eidet, J.R. Cultured Human Retinal Pigment Epithelial (hRPE) Sheets: A Search for Suitable Storage Conditions. Microsc. Microanal. 2018, 24, 147-155. [CrossRef]

36. Kitahata, S.; Tanaka, Y.; Hori, K.; Kime, C.; Sugita, S.; Ueda, H.; Takahashi, M. Critical Functionality Effects from Storage Temperature on Human Induced Pluripotent Stem Cell-Derived Retinal Pigment Epithelium Cell Suspensions. Sci. Rep. 2019, 9, 2891. [CrossRef]

37. Wang, A.W.; Zhang, H.; Ikemoto, I.; Anderson, D.J.; Loughlin, K.R. Reactive oxygen species generation by seminal cells during cryopreservation. Urology 1997, 49, 921-925. [CrossRef]

38. Honda, S.; Weigel, A.; Hjelmeland, L.M.; Handa, J.T. Induction of Telomere Shortening and Replicative Senescence by Cryopreservation. Biochem. Biophys. Res. Commun. 2001, 282, 493-498. [CrossRef]

39. Pegg, D.E. The History and Principles of Cryopreservation. Semin. Reprod. Med. 2002, 20, 005-014. [CrossRef]

40. Ahmado, A.; Carr, A.-J.; Vugler, A.A.; Semo, M.; Gias, C.; Lawrence, J.M.; Chen, L.L.; Chen, F.K.; Turowski, P.; Da Cruz, L.; et al. Induction of Differentiation by Pyruvate and DMEM in the Human Retinal Pigment Epithelium Cell Line ARPE-19. Investig. Opthalmol. Vis. Sci. 2011, 52, 7148-7159. [CrossRef] 
41. Jackson, C.J.; Aabel, P.; Eidet, J.R.; Messelt, E.B.; Lyberg, T.; Von Unge, M.; Utheim, T.P. Effect of Storage Temperature on Cultured Epidermal Cell Sheets Stored in Xenobiotic-Free Medium. PLoS ONE 2014, 9, e105808. [CrossRef]

42. Eidet, J.R.; Utheim, Ø.A.; Islam, R.; Lyberg, T.; Messelt, E.B.; Dartt, D.A.; Utheim, T.P. The Impact of Storage Temperature on the Morphology, Viability, Cell Number and Metabolism of Cultured Human Conjunctival Epithelium. Curr. Eye Res. 2015, 40, 30-39. [CrossRef] [PubMed]

43. Islam, R.; Jackson, C.J.; Eidet, J.R.; Messelt, E.B.; Corraya, R.M.; Lyberg, T.; Griffith, M.; Dartt, D.A.; Utheim, T.P. Effect of Storage Temperature on Structure and Function of Cultured Human Oral Keratinocytes. PLoS ONE 2015, 10, e0128306. [CrossRef] [PubMed]

44. Slikker, W.; Desai, V.G.; Duhart, H.; Feuers, R.; Imam, S.Z. Hypothermia enhances bcl-2 expression and protects against oxidative stress-induced cell death in chinese hamster ovary cells. Free. Radic. Biol. Med. 2001, 31, 405-411. [CrossRef]

45. Park, H.J.; Lyons, J.C.; Ohtsubo, T.; Song, C.W. Acidic environment causes apoptosis by increasing caspase activity. Br. J. Cancer 1999, 80, 1892-1897. [CrossRef] [PubMed]

46. Marmor, M.F. Control of subretinal fluid: Experimental and clinical studies. Eye 1990, 4, 340-344. [CrossRef]

47. Dunn, K.; Aotaki-Keen, A.; Putkey, F.; Hjelmeland, L. ARPE-19, A Human Retinal Pigment Epithelial Cell Line with Differentiated Properties. Exp. Eye Res. 1996, 62, 155-170. [CrossRef]

48. Dunn, K.C.; Marmorstein, A.D.; Bonilha, V.L.; Rodriguez-Boulan, E.; Giordano, F.; Hjelmeland, L.M. Use of the ARPE-19 cell line as a model of RPE polarity: Basolateral secretion of FGF5. Investig. Ophthalmol. Vis. Sci. $1998,39,6$.

49. Tian, J.; Ishibashi, K.; Honda, S.; A Boylan, S.; Hjelmeland, L.M.; Handa, J.T. The expression of native and cultured human retinal pigment epithelial cells grown in different culture conditions. Br. J. Ophthalmol. 2005, 89, 1510-1517. [CrossRef]

50. Luo, Y.; Zhuo, Y.; Fukuhara, M.; Rizzolo, L.J. Effects of Culture Conditions on Heterogeneity and the Apical Junctional Complex of the ARPE-19 Cell Line. Investig. Opthalmol. Vis. Sci. 2006, 47, 3644-3655. [CrossRef]

51. Geisen, P.; McColm, J.R.; King, B.M.; Hartnett, M.E. Characterization of Barrier Properties and Inducible VEGF Expression of Several Types of Retinal Pigment Epithelium in Medium-Term Culture. Curr. Eye Res. 2006, 31, 739-748. [CrossRef] [PubMed]

52. Samuel, W.; Jaworski, C.; Postnikova, O.A.; Kutty, R.K.; Duncan, T.; Tan, L.X.; Poliakov, E.; Lakkaraju, A.; Redmond, T.M. Appropriately differentiated ARPE-19 cells regain phenotype and gene expression profiles similar to those of native RPE cells. Mol. Vis. 2017, 23, 60-89. [PubMed]

53. Tian, J.; Ishibashi, K.; Handa, J.T. The expression of native and cultured RPE grown on different matrices. Physiol. Genom. 2004, 17, 170-182. [CrossRef] [PubMed]

54. Utheim, T.P.; Raeder, S.; Utheim, Ø.A.; Cai, Y.; Roald, B.; Drolsum, L.; Lyberg, T.; Nicolaissen, B. A novel method for preserving cultured limbal epithelial cells. Br. J. Ophthalmol. 2006, 91, 797-800. [CrossRef] [PubMed]

55. Utheim, T.P.; Islam, R.; Fostad, I.G.; Eidet, J.R.; Sehic, A.; Olstad, O.K.; Dartt, D.A.; Messelt, E.B.; Griffith, M.; Pasovic, L. Storage Temperature Alters the Expression of Differentiation-Related Genes in Cultured Oral Keratinocytes. PLoS ONE 2016, 11, e0152526. [CrossRef]

56. Jackson, C.; Eidet, J.R.; Reppe, S.; Aass, H.C.D.; Tønseth, K.A.; Roald, B.; Lyberg, T.; Utheim, T.P. Effect of Storage Temperature on the Phenotype of Cultured Epidermal Cells Stored in Xenobiotic-Free Medium. Curr. Eye Res. 2015, 41, 757-768. [CrossRef]

57. Pellegrin, S.; Mellor, H. Actin stress fibres. J. Cell Sci. 2007, 120, 3491-3499. [CrossRef]

58. Tojkander, S.; Gateva, G.; Lappalainen, P. Actin stress fibers-assembly, dynamics and biological roles. J. Cell Sci. 2012, 125, 1855-1864. [CrossRef]

59. Narimatsu, T.; Ozawa, Y.; Miyake, S.; Kubota, S.; Hirasawa, M.; Nagai, N.; Shimmura, S.; Tsubota, K. Disruption of Cell-Cell Junctions and Induction of Pathological Cytokines in the Retinal Pigment Epithelium of Light-Exposed Mice. Investig. Opthalmol. Vis. Sci. 2013, 54, 4555-4562. [CrossRef]

60. Eidet, J.R.; Pasovic, L.; Maria, R.; Jackson, C.J.; Utheim, T.P. Objective assessment of changes in nuclear morphology and cell distribution following induction of apoptosis. Diagn. Pathol. 2014, 9, 92. [CrossRef] 
61. Vermes, I.; Haanen, C.; Steffens-Nakken, H.; Reutellingsperger, C. A novel assay for apoptosis Flow cytometric detection of phosphatidylserine expression on early apoptotic cells using fluorescein labelled Annexin V. J. Immunol. Methods 1995, 184, 39-51. [CrossRef]

62. Khan, A.Z.; Utheim, T.P.; Jackson, C.J.; Reppe, S.; Lyberg, T.; Eidet, J.R. Nucleus Morphometry in Cultured Epithelial Cells Correlates with Phenotype. Microsc. Microanal. 2016, 22, 612-620. [CrossRef] [PubMed]

Sample Availability: Samples of the compounds are not available from the authors.

Publisher's Note: MDPI stays neutral with regard to jurisdictional claims in published maps and institutional affiliations.

(C) 2020 by the authors. Licensee MDPI, Basel, Switzerland. This article is an open access article distributed under the terms and conditions of the Creative Commons Attribution (CC BY) license (http://creativecommons.org/licenses/by/4.0/). 